\title{
PRIOR ACCOUNTING KNOWLEDGE OF FIRST-YEAR STUDENTS AT TWO SOUTH AFRICAN UNIVERSITIES: CONTRIBUTING FACTOR TO ACADEMIC PERFORMANCE OR NOT?
}

\author{
E. Papageorgiou \\ Department: Accountancy \\ University of the Witwatersrand \\ Johannesburg, South Africa \\ e-mail: Elmarie.Papageorgiou@wits.ac.za
}

\section{R. Carpenter}

Department: Accounting

University of Cape Town

Cape Town, South Africa

e-mail: riley.carpenter@uct.ac.za

\section{ABSTRACT}

Factors that influence students' academic performance are essential for students, lecturers, universities, Department of Higher Education, curriculum developers and professional bodies. This study focuses on the prior accounting knowledge of students entering higher education, one of many factors that could influence students' academic performance and ultimate success graduating in the time allocated for the degree. The reasons for revisiting this factor are firstly, admission requirements regarding Accounting as school subject for students applying for the "Bachelor of Commerce (BCom)" degree majoring in Accounting and the Accounting degree in becoming a Chartered Accountant (CA) are different among South African universities; secondly, since 2008 there was a dramatically change to the "National Senior Certificate (NSC)" examination; and lastly, comparing students' prior accounting knowledge as a contributing factor or not of international studies with South African studies. An investigation was launched to study the effect of first-year Accounting students' academic performance whether Accounting was one of their school subjects before registered for a degree in Accounting at two universities in South Africa. The research method used a quantitative methodology. The findings of the study suggest a greater sensitivity and better understanding for students' prior accounting knowledge which might influence their academic performance. The value of the study is an important contribution to the consideration of admission requirements for students applying for a degree in Accounting at universities in South Africa.

Keywords: academic performance, Accounting students, admission requirements, university, prior knowledge, South Africa 


\section{INTRODUCTION}

Factors that influence the academic performance of students, that may prevent students from graduating or extend their degree with a year or longer, have attracted the attention of many researchers; factors such as students' age, gender, attitude, extended curriculum, personality, diversity, transition from secondary to tertiary education and prior academic achievement (Duff 2004; Bergin 2001; Chansarkar and Michaeloudis 2001; Lubbe 2017; Papageorgiou and Halabi 2014; Van Rensburg, Penn and Haiden 1998; Woollacott, Snell and Laher 2013; Duff and Mladenovic 2015; Papageorgiou 2017; Papageorgiou and Callaghan 2018; Steenkamp, Baard and Frick 2009). For some students who enter higher education, career and educational ambitions, individual benefits and quality of learning are the main drivers (Samsuddin, Khairani, Wahid and Sata 2015; Biggs 2003) to academic success. The adaptation from school to higher education could be an overwhelming and traumatic period for entry-level students (Woollacott et al. 2013), but could be an exciting period for other students. Arquero, Byrne, Flood and Gonzalez $(2009,295)$ recommended that "future research [must] focus on students who struggle [academically] and if there is any hope of improving student progression".

Previous studies explored many factors that could influence academic success and reported different findings which make it challenging for lecturers and curriculum planners to determine the main factor/s that influence academic success to be successful other than the uncontrollable factors which may effect academic performance, such as age, gender, race, socio-economic background, home environment and language (Van Wyk 2011; Duff 2004; Bergin 2001; Chansarkar and Michaeloudis 2001; Lubbe 2017; Papageorgiou and Halabi 2014; Woollacott et al., 2013). In contrast, the controllable factor, "prior academic achievement remains the best predictor of academic performance" (Duff 2004, 425). This study contributes to whether students' prior accounting knowledge is to their advantage who aim in qualifying as Chartered Accountants $(\mathrm{CA}(\mathrm{SA}))^{1}$ or are studying towards a Bachelor of Commerce degree majoring in Accounting. The reasons for revisiting the factor whether prior accounting knowledge is a contributing factor or not, to students' academic success are threefold: firstly, students' admission requirements applying for a BCom degree majoring Accounting and Accounting degree in becoming a CA are different among universities regarding Accounting as a pre-requisite school subject (Uni 1 2017; Uni 2 2017a; Uni 3 2018; Uni 4 2018); secondly, Grade 12 subjects have changed significantly with the introduction of the "National Senior Certificate (NSC)" examination in 2008 regarding Accounting as a Grade 12 subject (also other subjects) from being a higher and standard grade subject to a subject with no differentiation (DoE 2018); and lastly, comparing students' prior accounting knowledge as a contributing factor or not of international studies with South African studies. The study of Seow, Pan and 
Tay (2011) focused on studies done in the United Kingdom, Hong Kong, Malaysia, United States of America, Australia, New Zealand and Singapore examining variables that affect the accounting students' academic performance with specific reference to prior accounting knowledge. No mention has been made of studies conducted in Africa. The contribution of the study is to determine if students' prior accounting knowledge is significant as a contributing factor or not, since the "core content of the existing BCom curriculum has remained unchanged for many years" (Lubbe 2017, 61) at many institutions in South Africa and therefore institutions, lectures and the profession need to revisit these criteria in a new setting.

The purpose of the study focused on the effect of the academic performance of first-year accounting students registered for a degree in Accounting at two universities in South Africa, whether students before entering the university had Accounting as a subject or not. The two universities under review for this study are located in Africa, ranked as the highest and second highest as per the "Center for World University Rankings" (CWUR) ${ }^{2}$ (CWUR 2018a) and are known for their large classes and diverse range of prior knowledge students have brought to lectures (Müller, Prinsloo and Du Plessis 2007; Scott, Yeld and Hendry 2007; Papageorgiou 2016).

This study was motivated by the following two studies. Firstly, Van Rensburg et al. (1998) explored the influence of Accounting as a school subject on the accounting performance of students at an university in South Africa and confirmed that prior Accounting exposure enhanced the academic performance of students. The current study expands the prior research of Van Rensburg et al. (1998) by investigating a more recent population (twenty years later) of accounting students at two universities in South African in which the accounting curriculum and student demographics differs. Van Rensburg et al. (1998) concluded that former accounting knowledge describes only 4 per cent of the disparity in the Accounting marks. And secondly, Bergin (2001) investigated the effect if students had Accounting at school on the first-year students' academic performance registered for Accounting at a university in America and confirmed that there was no association between students who had prior Accounting knowledge before entering the university and students' academic performance.

This study's findings concluded that a significant relationship was found between the academic performance of students and whether Accounting was a school subject, a contributing factor to academic success, in relation of not having Accounting as a school subject. Additionally, this study may serve to guide scholars and school guidance teachers to make the correct degree choices to prevent students from applying for a degree that might cause them frustration and eventually, disappointment (Seow et al. 2011; Seow, Pan and Tay 2014) and/or set them up for failure. The research was guided by the following questions: 
- Is there a correlation between students' academic performance and students' prior knowledge of accounting?

- What are the relationships between students' academic performance and the grade obtained in Accounting in Grade 12?

The purpose of the study is addressed by the following objectives:

- to determine if any correlations exist between the academic performance of Accounting students and;

- exposure to high school Accounting, and

- the grade obtained for Accounting in the "National Senior Certificate (NSC)".

This study initiates by reviewing earlier research on prior accounting knowledge prior to registration for an undergraduate BCom degree in Accounting in South African universities. Thereafter the literature study is discussed, followed by the research method, results, conclusion and limitations. This is followed by the recommendations for future research.

\section{LITERATURE REVIEW}

The NSC examination pass rates are important indicators of secondary school education to serve as admission requirement entering higher education in South Africa. The Grade 12 "pass rate, which was as low as 40 per cent in the late 1990s, has improved considerably", in "2014 South Africa's Grade 12 scholars achieved a pass rate of 75.8 per cent", however the "national pass rate in the 2015 NSC Grade 12 examinations dropped to 70.7 per cent", and increased in 2017 to 75.1 per cent, an increase of 4.4 per cent over a period of three years (Department of Basic Education RSA 2018). Some universities also rely on other predictors as part of the selections process before acceptance like the National Benchmark Test (NBT) (NBT 2018) and other practical measures, especially for the Health and Engineering Faculties.

Higher education institutions accept student applications provisionally if students meet the institutions" admission requirements to which they apply. These "admission requirements, which vary from degree, are posted on university websites and/or are available at university enrolment centres in order for students to apply" (Papageorgiou 2016, 4). The scholars' marks obtained in the final examination at school (Grade 12) are used at some universities as the only requirement to enter higher education. However, at most universities, the admission point or 
score are used purely as an admission's guideline to the university. If students meet these requirements, students are only offered a provisional place at the university but universities do not secure a place for the degree until the final results of the NSC examination are made public. Final offers are made to applicants who were provisionally accepted; as this depends on the availability of places for the degree, final results and other entry requirements where applicable. The main admission requirements for the BCom degree in Accounting and Accounting degree in becoming a CA are that students who applied for these degrees must have passed and obtained a certain grading for the following subjects; English, Mathematics and in some circumstances, Accounting. Each university in South Africa has their own criteria of the grading a scholar must obtain in each of these subjects to apply for these degrees. Accounting lecturers and curriculum developers confirm that previous research has shown that those scholars, registered for the Accounting programme at universities, who obtained higher Mathematics' marks in Grade 12 outperform their peers comparing to scholars with lower Mathematic marks (Baard et al. 2010). In addition, the marks obtained for English and, at some universities the marks for, Accounting in the final NSC examination are assumed to be a realistic predictor of students' academic performance registered for a degree in Accounting (Müller et al. 2007; Baard et al. 2010; Papageorgiou 2017; Du Plessis, Müller and Prinsloo 2005).

International research has found a range of relationships between prior knowledge, resulting from passing Accounting at secondary-level and students' academic performance at higher education institutions. While there is evidence of both negative relationships and inconclusive findings, the majority of studies conclude that a positive relationship exists. In the study by Bergin (2001), no relationship was found between first-year accounting students with former Accounting knowledge and student performance. Furthermore, Baldwin and Howe (1982) investigated prior accounting knowledge and first-year accounting students' performance at the Arizona State University and found that there was no difference in students' performance whether the students had school Accounting or not. Mitchell (1988, 280) investigated a "first year Accounting class and accounting students" performance at the University of Edinburgh, United Kingdom”. The study confirmed that students who had school Accounting scored somewhat higher than students with no Accounting in school. Thus, the "difference in academic performance was minimal and not significant at the 5 per cent level" of confidence (Mitchell 1988, 283).

Doran, Bouillon and Smith (1991) concluded that students with former Accounting knowledge in school have a tendency to score higher academic marks at university comparing to students with no former Accounting knowledge. Aidoo-Buameh and Ayagre (2013) explored the relationship between prior accounting knowledge and accounting students' academic 
performance at the Central University College in Ghana. They found that students' Accounting marks were statistically significant of students who had former accounting knowledge comparing to students who had no prior knowledge of accounting. Akenbor and Ibanichuka $(2014,23)$ investigated if institutional factors affect first-year accounting students' academic performance enrolled at a university in Nigeria and suggested that school Accounting need to be a pre-requisite "with a minimum pass grade should be part of the requirements for gaining admission into programmes where principles of accounting is offered".

Gul and Fong $(1993,33)$ investigated the "success for introductory accounting students at the University of Hong Kong" and concluded that if students had school Accounting it was an important contributing factor to the success of students. Previous studies on first-year Accounting courses concluded a significant positive correlation between students' prior academic achievement and academic success (Arquero et al. 2009; Byrne and Flood 2005). Schroeder (2001) confirmed that students who were exposed to Accounting at school longer than a year before enrolling for an Accounting degree obtained higher marks in an Accounting course at university than those students who were exposed to Accounting less than a year at school level. Arquero et al. $(2009,279)$ explored hundred and eighty accounting students' preparedness and academic performance enrolled for "Accounting at a Spanish university and confirmed that students' interest in accounting and the experience of Accounting as a subject at school were significantly correlated with academic performance”. Xiang and Gruber (2013) investigated the following two groups: group one, students who had Accounting at school, while group two, had no accounting exposure and the findings concluded a positive and significance relationship between these two groups.

In South Africa, prior studies (Van Rensburg et al. 1998; Rowlands 1988) confirmed the positive association between students' knowledge of accounting prior of entering universities and students' academic performance in an Accounting course. In contrast to Bergin (2001), Rowlands (1988) and Van Rensburg et al. (1998) confirmed that students with former accounting exposure before entering the university performed better at the beginning of the Accounting course than students with no prior accounting knowledge. Papageorgiou (2017, 209) “investigated Accounting students' profile $(\mathrm{N}=3075)$ versus academic performance over a period of five years, 2010 to 2014, at a South African university" and confirmed that less students passed Accounting in their first year at university who did not have school Accounting in relation to students who had Accounting at school. Papageorgiou's finding (2017) confirms with the findings of Akenbor and Ibanichuka (2014) and Aidoo-Buameh and Ayagre (2013). The study of Lubbe $(2017,68)$ states that "students struggle to make sense of business and financial concepts" due to their "limited prior knowledge of commercial and business contexts" 
and suggests extending the curriculum with one year to a four-year degree comparing to a threeyear degree. Pullen, Toerien and Anthony (2015) explored factors that effect students' academic performance enrolled for an "advanced management accounting course at the University of the Western Cape" and concluded that students who obtained a higher final mark in school outperformed their peers who obtained a lower final high school mark. The study of Jansen and De Villiers $(2016,1)$ identified "factors that have a significant relationship with students performance in accounting" in their third-year "at the University of the Western Cape" and concluded that results obtained in Grade 12 are "significantly related to their performance in the final year undergraduate accounting module".

This study investigated the admission requirements for a BCom Degree majoring in Accounting and Accounting Degree in becoming a CA at two South African universities to determine whether school Accounting should be a prerequisite and/or a subject requirement before admission. The admission requirements regarding "Accounting as a school subject" for the degrees were sourced from the two universities official website (Uni 2 2017a; Uni 2 2017b; Uni 1 2017). The one university under review indicated that it is not essential to have done high school Accounting if students apply for an Accounting programme and the other university does not indicate any requirements if students had Accounting as a subject in school. Other South African universities indicated similar requirements; one university divides students who have registered for Accounting as a first-year subject into groups, group one, students that had school and group two, students without Accounting in Grade 12 (Uni 3 2018; Uni 4 2018). Furthermore, at another university students are required to write an "Accounting proficiency test" (Uni 3 2018) and at one university students are required to obtain "70 per cent for Mathematics OR 60 per cent for Mathematics and 70 per cent for Accounting in the NSC examination" (Uni 5 2018). Thus in summary, for the same degree at universities, different admissions requirements are applicable.

SAICA (2017a) states that if students had Accounting in their final year in Grade 12, it might be beneficial for applicants when applying for the Accounting degree in becoming a CA at the university. At most universities school Accounting is not a pre-requisite in applying for the Accounting degree. Both universities under review used similar criteria in determining the admission requirements of potential students, a score or points per candidate is calculated based on their grades obtained in the NSC examinations. If the student's score or points is equal or above the required score or points achieved, the student will be considered for a place in the programme and will be provisionally accepted for these degrees until the final NSC marks are published (Uni 2 2017a; Uni 1 2017). Universities only have a certain number of places available and can only offer these places to students. This process could be overwhelming and 
traumatic for some students as they are not sure if the university will make them an offer even if they have the required points/scores, while this process could be very exciting for some students who may receive offers from more than one university and have the luxury to select their first choice. The current trend in South Africa is to apply to more than one university due to the high demand and overpopulated universities. This could also be a financial burden due to increased traveling and accommodation costs if students do not receive an offer from their preferred university close to their place of residence during their studies.

\section{RESEARCH DESIGN}

The researchers used a quantitative methodology, exploratory in nature (Ryan, Scapens and Theobald 2002; Blumberg, Cooper and Schindler 2014; Leedy and Ormrod 2010. This research explored prior Accounting knowledge and academic performance of 1244 accounting students registered for an Accounting degree at two universities in South Africa. At both universities, the Accounting courses are offered over one academic year. Student assessments are tests, concepts tests, assignments and projects with one final written examination at the end of the year. Students attend lectures and tutorials.

\section{Collection and analysis of data}

The universities' computerised database was used to collect data in a spreadsheet indicating the students' academic marks for the final exam and if students had Accounting in Grade 12 and the grading obtained in the NSC examination for Accounting. A software package, "Statistical Package for the Social Sciences (IBM SPSS Statistics V25)", was used to analyse the data identifying frequencies and determining whether any correlations occur between first-year accounting students' academic performance and if students had Accounting in their final year of school.

\section{RESULTS AND DISCUSSION}

The study reports on the demographics of 1244 first-year accounting students; nearly 78 per cent of the students had Accounting at school. The aims of the study were addressed in conducting the "Pearson chi-square tests for independence" to determine whether there was any significant correlation between students' academic performance and Accounting at school level as well as and marks obtained in Accounting at school.

\section{Correlation between Accounting students' academic performance in and Accounting at school}

Students' success at both universities are defined as follows; students who passed Accounting who obtained 50 per cent and above, and students who failed Accounting obtained less than 50 
per cent. Students who failed first-year Accounting must repeat the year if the student wishes to continue with the degree or may decide the way forward to their own discretion. The students' accounting marks at each university under review were categorised into two categories; Category 1: Pass, students obtained 50 per cent and above and Category 2: Fail, students obtained less than 50 per cent; both categories include students with and without Accounting as a subject at school. Subsequently associations were tested between the two categorical variables. The statistical tests compare the values that would be expected if there were no association between the two variables and the observed frequencies that occur in each of the categories. Chi-square tests for University one (Uni 1) and University two (Uni 2) indicated both a significant relationship between academic success and whether students had school Accounting, Uni 1, $\chi 2(1, \mathrm{n}=559)=4.695, \mathrm{p}=.013$. and Uni $2, \chi^{2}(1, \mathrm{n}=685)=13.034$, $\mathrm{p}=.000$, confirming University 2 with a higher value indicating a stronger association between the variables. The results of the study of Aidoo-Buameh and Ayagre (2013) confirm with the results of this study that accounting prior to university is a contributing factor to academic performance.

\section{Results of University 1}

A total of 26.3 per cent of students without Accounting failed Accounting I in their first year of study comparing to 16.1 per cent of students with Accounting failed Accounting I.

\section{Results of University 2}

A total of 7.8 per cent of students with Accounting failed Accounting I in their first year of study comparing to 2.1 per cent of students with Accounting failed Accounting I.

\section{Results of University 1 and University 2}

A total of 12.9 per cent of students without Accounting failed Accounting I in their first year of study comparing to 9.1 per cent of students with Accounting failed Accounting I. From the results of both universities the pass rate of Accounting I for students without Accounting as a Grade 12 subject are probably lower than students who had Accounting in Grade 12. Another interesting fact is that fewer students that had Accounting in Grade 12 of University 2 failed Accounting I comparing to students from University 1. A possible reason could be that some universities do not distinguish or differentiate between students with and without Accounting and the students are enrolled in one class while at other universities divide students into the two streams/classes; students with prior accounting and students with no prior accounting at school level (Uni 3 2018). Some universities indicate that students need to register for two different 
accounting courses in their first year; the one course for students who passed Accounting in the NSC with at least 60 per cent and the second course for students who had no school Accounting (Uni 3 2018; Uni 4 2018). In addition, students without Accounting in their final year must write a compulsory accounting proficiency test and the results will determine if the student must register for a different accounting course comparing to students that had Accounting in Grade 12 (Uni 4 2018) registered for the same degree.

\section{Correlation between Accounting students' academic performance and marks obtained in Accounting as a school subject in Grade 12}

Almost 78 per cent of the total sample of students had Accounting and 77.2 per cent of these students obtained an A grade, consisting of 78.5 per cent and 75.9 per cent respectively of Uni 1 and Uni 2 of the total number of students registered for an Accounting degree at each university. For both universities under review Accounting was not required as part of the admission requirements to be accepted for the Accounting degree and students who obtained any grade for school Accounting or had no Accounting at school can be accepted into the desired programme (Uni 1 2017; Uni 2 2017a) compared to other South African universities (Uni 3 2018; Uni 4 2018; Uni 5 2018). At these universities the following were required from students registered for an Accounting degree: university one, students with no Accounting at school are required to write an accounting proficiency test, university two, a different Accounting course was offered to students that had Accounting at school comparing to students without Accounting as a subject in school and lastly university three, one of the requirements are that students must have obtained 60 per cent for Mathematics and 70 per cent for Accounting in the NCS examination or 70 per cent in Mathematics. The grades students obtained in Accounting in Grade 12 are reflected in Table 1; grades are categorised as follow; "A-grade (80-100\%), Bgrade (70-79\%), C-grade (60-69\%) and D-grade (50-59\%)". Additionally, only one student from University 1 and four students from University 2 obtained a grade other than grades A to D.

A "Chi-squared test" was conducted that confirmed a significant correlation between the academic performance of students and the grade obtained for school Accounting for both universities, $\chi 2(4, \mathrm{n}=964)=1200.0, \mathrm{p}=.000$. Thereafter, a "Kruskal-Wallis test" was conducted for both universities comparing the final marks obtained for Accounting at university with the grades obtained for Accounting at school and confirmed a statistically significant difference in marks obtained across the following five grade categories; (Grade A, $n=744$, Grade B, $n=177$, Grade C, $n=35$, Grade D, $n=3$, Other, $n=4), \chi 2(4, n=964)=27.964$, $\mathrm{p}=.000$. 
Table 1: Students' Accounting grades obtained in Grade 12

\begin{tabular}{|c|c|c|c|c|c|c|c|}
\hline \multirow{2}{*}{ University } & \multirow{2}{*}{$\begin{array}{l}\text { Yes, had Accounting at } \\
\text { school }\end{array}$} & \multicolumn{5}{|c|}{ Accounting Grades obtained in Grade 12} & \multirow{2}{*}{ Total } \\
\hline & & A & B & C & D & Other & \\
\hline \multirow{2}{*}{$\begin{array}{l}\text { University } 1 \\
\text { (Uni 1) }\end{array}$} & Count total university & 379 & 86 & 17 & & 1 & 483 \\
\hline & $\%$ who had Acc in school & $78.5 \%$ & $17.8 \%$ & $3.5 \%$ & & $.2 \%$ & $100.0 \%$ \\
\hline \multirow{2}{*}{$\begin{array}{l}\text { University } 2 \\
\text { (Uni 2) }\end{array}$} & Count total university & 365 & 91 & 18 & 3 & 4 & 481 \\
\hline & $\%$ who had Acc in school & $75.9 \%$ & $18.9 \%$ & $3.7 \%$ & $.6 \%$ & $.8 \%$ & $100.0 \%$ \\
\hline \multirow{2}{*}{ Total } & Count: Total group & 744 & 177 & 35 & 3 & 5 & 964 \\
\hline & $\%$ who had Acc in school & $59.8 \%$ & $14.2 \%$ & $2.8 \%$ & $.2 \%$ & $.4 \%$ & $100.0 \%$ \\
\hline
\end{tabular}

The data was further analysed to determine if any correlations exist. The final Accounting I marks of students who have failed or passed Accounting I were compared with Accounting in Grade 12 grades for both universities. A Kruskal-Wallis test was conducted for each category, "Fail" and "Pass" for both universities and a statistically significant difference was found of students who had failed and passed Accounting I compared to the grades obtained across the respective groups. The category "Fail" had four grade categories; A, B, C and other, while category "Pass" had five grade categories; A, B, C, D and other. Very interestingly, the three students of University 2 who obtained a D-grade for Accounting in Grade 12 passed Accounting I in their first year of study. The test for both universities revealed for category "Fail" (Grade A, $n=51$, Grade B, $n=27$, Grade C, n=8, Other, $n=2), \chi^{2}(3, n=88)=26.690, p=.000$ while category "Pass" (Grade A, n=693, Grade B, $n=150$, Grade C, $n=27$, Grade D, n=3, Other, $\mathrm{n}=3), \chi 2(4, \mathrm{n}=876)=49.376, \mathrm{p}=.000$. Surprisingly, 90.2 per cent of students from University I who failed Accounting I obtained an A-grade for Accounting in Grade 12 while only 9.8 per cent of students from University 2 who failed Accounting I obtained an A-grade for Accounting in Grade 12. This trend was prominent for grades B and C. The reason for this finding could be that some students may be overconfident at the beginning of the academic year and assume to be easy for the remainder of the year and sometimes comments like "I have done this in school" or "this is so boring, done the accounting equation" can be heard in lectures. With the introduction of new and more challenging topics, students are unprepared and fall behind and eventually, fail Accounting. In contrast, students without school Accounting either drop out early in the course due to poor results after the first Accounting test or began to work diligently and sometimes outperform students that had Accounting in school. The results confirmed that the majority of students who obtained an A grade for Accounting in school "Passed" first-year Accounting at university.

\section{CONCLUSION}

This study reflected on an investigation whether prior accounting knowledge is a contributing factor to academic performance or not of students registered for an Accounting degree 
programme at two universities in South Africa. The two objectives were, "To determine if any associations exists between the academic performance of first-year Accounting students and prior Accounting exposure at school level and marks obtained in Accounting as a Grade 12 subject". The objectives of the study were addressed to reflect the purpose of the study. The findings indicated that a significant association exists between students' academic performances that had high school Accounting compared to students that did not have Accounting prior of registering for the Accounting course. The studies of Rowlands (1988), Van Rensburg et al. (1998) and Uyar and Güngörmüş (2011) confirmed that if students had prior Accounting knowledge before enrolling as a student at the university inclines to improve the academic performance of students in their first year, however Bergin (2001) found no association between students' academic performance if students had prior Accounting in school or not.

This study concluded with evidence as to whether school Accounting is to the advantage of students before registering for an Accounting course for the BCom degree majoring in Accounting and Accounting degree for CAs. Furthermore, there are many factors that effect students' academic performance but one the these factors are whether or not to include Accounting as a pre-requisite in the admission requirements that may influence the academic performance of students. The results of this study may guide lecturers, curriculum developers and professional bodies to revisit the admission requirements at their universities. Recommendations from the study of Akenbor and Ibanichuka $(2014,23)$ were that "preuniversity Accounting with a minimum pass is a key success factor for achievement in Accounting and should be part of the requirements for gaining admission into programmes" of Accounting. SAICA (2017a) confirms; "having Accounting as a school subject could help you in your studies towards your degree, but at most universities this is not compulsory". Furthermore, the adaptation from school to university may be stress-free or less stress for students who had prior Accounting exposure before entering the $\mathrm{CA}$ and $\mathrm{BCom}$ degrees. Akenbor and Ibanichuka (2014) stated that students' entry requirements for an accounting degree at universities have a direct link on students' achievements in accounting courses. Unfortunately there are no assurances that students will ultimately graduate even if they successfully pass their first-year Accounting course for the degree they admitted for.

\section{LIMITATIONS}

There were three limitations to the study; firstly, only two South African universities were included in the study, secondly, only first-year Accounting students were included in the study majoring in Accounting. However, students in their second and third year of study were 
excluded in this study that could have contributed to the study in whether prior Accounting knowledge was to the advantage to students registered for an Accounting degree. Thirdly, there are definitely other factors that effect students' academic performance other than students that had school Accounting or did not have Accounting in school.

\section{FUTURE RESEARCH}

In summary, this study was within the South African context in higher education in Accounting studies of first-year students enrolled at two universities in one academic year to determine if prior accounting knowledge is a fundamental factor to students' academic success or not. The limitations of this study confirmed future recommendation that more replicative work is required to include other South African universities, to revisit SAICA's requirements and students' admission requirements before any general conclusions can be drawn on the influence of school Accounting on students' academic performance. In addition, further studies might contribute by tracking students' academic performance until graduation, identifying the type of school (government or private) students attended prior to university and whether it influence students' academic success.

\section{NOTES}

1. "A Chartered Accountant (South Africa) $(\mathrm{CA}(\mathrm{SA}))$ is associated with a person who has a professional accountancy degree, obtained an additional Honours degree or postgraduate diploma in Accounting, completed a three-year training contract, passed two board examinations and is a member of the South African Institute of Chartered Accountants (SAICA)" (SAICA 2017b).

2. "The CWUR has been publishing the only academic ranking of global universities that assesses the quality of education, alumni employment, research output, and citations without relying on surveys and university data submissions" (CWUR 2018b).

\section{REFERENCES}

Aidoo-Buameh, J. and P. Ayagre. 2013. "The effect of entry grades on academic performance of university Accounting students: A case of undergraduates on Central University College". Research Journal of Finance and Accounting 4(7): 198-206.

Akenbor, C. O. and E. A. L. Ibanichuka. 2014. "Institutional factors influencing the academic performance of students in principles of Accounting". International Journal of Higher Education 1: 15-26.

Arquero, J. L., M. Byrne, B. Flood and J. M. Gonzalez. 2009. "Motives, expectations, preparedness and academic performance: A study of students of accounting at a Spanish university". Revista de Contabilidad-Spanish Accounting Review 12(2): 279-300.

Baard, R. S., L. P. Steenkamp, B. L. Frick and K. Kidd. 2010. "Factors influencing success in first-year Accounting as a South African university: The profile of a successful first year Accounting student". South African Journal of Accounting Research 24(1): 129-147.

Baldwin, B. A. and K. R. Howe. 1982. "Secondary-level study of accounting and subsequent performance in the first college course". The Accounting Review LVII(3): 619-626. 
Bergin, J. L. 2001. "The effect of previous accounting study on student performance in the first collegelevel financial accounting course". Issues in Accounting Education: 19-28.

Biggs, J. B. 2003. Teaching for quality learning at university. $2^{\text {nd }}$ Edition. Milton Keynes: The Society for Research into Higher Education, Open University Press.

Blumberg, B. F., D. R. Cooper and P. S. Schindler. 2014. Business research methods. $4^{\text {th }}$ Edition. London: McGraw Hill.

Byrne, M. and B. Flood. 2005. “A study of accounting students' motives, expectations and preparedness for higher education". Journal of Further and Higher Education 29(2): 111-124.

Center for World University Rankings. 2018a. Center for World University Rankings by institution. http://cwur.org/

Center for World University Rankings. 2018b. About the Center for World University Rankings. http://cwur.org/about.php

Chansarkar, B. A. and A. Michaeloudis. 2001. "Student profiles and factors affecting performance". International Journal of Mathematics Education in Science Technology 32(1): 97-104.

CWUR see Center for World University Rankings.

Department of Basic Education RSA. 2018. National Senior Certificate Examination 2018. Department of Basic Education, Republic of South Africa. http://www.education.gov.za/Portals/0/ Documents/Reports/2017\%20NSC\%20School\%20Performance\%20Report.pdf?ver=2017-0104-161424-000.

Department of Education (DoE). 2018. National Senior Certificate. http://ncedu.ncape.gov.za/ index.php/teacher/national-senior-certificate

Doran, B. M., M. L. Bouillon and C. G. Smith. 1991. "Determinants of student performance in Accounting Principles I and II". Issues in Accounting Education 6(1): 74-84.

Du Plessis, A., H. Müller and P. Prinsloo. 2005. "Determining the profile of the successful first-year accounting student”. South African Journal of Higher Education 19(4): 684-698.

Duff, A. 2004. "Understanding academic performance and progression of first-year accounting and business economics undergraduates: the role of approaches to learning and pro academic achievement". Accounting Education 13(4): 409-430.

Duff, A. and R. Mladenovic. 2015. Antecedents and consequences of accounting students' approaches to learning: A cluster analytic approach". The British Accounting Review 57: 321-338.

Gul, F. A. and S. C. C. Fong. 1993. "Predicting success for introductory accounting students: Some further Hong Kong evidence". Accounting Education 2(1): 33-42.

Jansen, J. and C. de Villiers. 2016. "Determinants of student performance in an accounting degree programme". South African Journal of Accounting Research 33(1): 1-28.

Leedy, P. D. and J. E. Ormrod. 2010. Practical research. Boston, MA: Pearson.

Lubbe, I. 2017. "Challenges for curriculum design: Considerations for a four-year business and accounting degree in South Africa". South African Journal of Accounting Research 31(1): 60-82.

Mitchell, F. 1988. "High school accounting and student performance in the first level university accounting course: A UK study". Journal of Accounting Education Research 6: 279-291.

Müller, H., P. Prinsloo and A. du Plessis. 2007. "Validating the profile of a successful first-year Accounting student". Meditari Accounting Research 15(1): 19-33.

National Benchmark Test. 2018. National Benchmark Test. http://www.nbt.ac.za/

NBT see National Benchmark Test.

Papageorgiou, E. 2016. "Evidence of Accounting as a Grade 12 subject for first-year Accounting students at a South African university". Meditari Accountancy Conference Proceedings, June, Pilansburg, South Africa. https://www.google.co.za/search?source=hp\&ei=5uLTXfCCNaaQlw TF97LIDQ \&q $=$ Evidence + of + Accounting + as $+a+$ Grade $+12+$ subject + for + first-year + Accounting + students $+\mathrm{at}+\mathrm{a}+$ South + African + university $\% \mathrm{E} 2 \% 80 \% 9 \mathrm{D}$ 
Papageorgiou, E. 2017. "Accounting students' profile versus academic performance: A five-year analysis". South African Journal of Higher Education 31(3): 209-229.

Papageorgiou, E. and C. W. Callaghan. 2018. "Personality and adjustment in South African higher education accounting studies". South African Journal of Higher Education, (Published on-line March 2018 https://www.tandfonline.com/doi/full/10.1080/10291954.2018.1442649).

Papageorgiou, K. and A. K. Halabi. 2014. "Factors contributing toward student performance in a distance education accounting degree". Meditari Accounting Research, 22(2): 211-223.

Pullen, E., F. Toerien and J. Anthony. 2015. Student endogenous factors that impact on performance in advanced management accounting: An exploratory study. South African Accounting Association Conference Proceedings, East London, South Africa, June.

Rowlands, J. E. 1988. "The effect of secondary school Accounting study on university Accounting performance". De Ratione 2(2): 17-21.

Ryan, B., R. W. Scapens and M. Theobald. 2002. Research method and methodology in finance and accounting. $2^{\text {nd }}$ Edition. London: South-Western.

SAICA see South African Institute for Chartered Accountants.

Samsuddin, M. E., N. S. Khairani, E. A. Wahid and F. H. A. Sata. 2015. "Awareness, motivations and readiness for professional Accounting education: A case of Accounting students in UiTM Johor". Procedia Economics and Finance 31: 124-133.

Schroeder, N. W. 2001. "Previous accounting education and college-level accounting exam performance". Issues in Accounting Education: 37-47.

Scott, I., N. Yeld and J. Hendry. 2007. A case for improving teaching and learning in South African higher education. Higher Education Monitor No. 6. Pretoria: Council on Higher Education.

Seow, P-S., G. Pan and J. Tay. 2011. In search of a different accounting graduate: Entry-point determinants of students' performance in an undergraduate accountancy degree programme in Singapore. https://ink.library.smu.edu.sg/cgi/viewcontent.cgi?referer=http://www.google.co.za

Seow, P-S., G. Pan and J. Tay. 2014. "Revisiting the determinants of students' performance in an undergraduate accountancy degree programme in Singapore". Global Perspectives on Accounting Education 11: 1-23

South African Universities (SA Universities). 2018. South African Universities. http://africa universities.org/south-africa/

South African Institute for Chartered Accountants. 2017a. SAICA Accredited Programmes. https://www.saica.co.za/LearnersStudents/InformationonEducationProviders/InformationonAccr editedProgrammes/tabid/465/language/en-ZA/Default.aspx

South African Institute for Chartered Accountants. 2017b. SAICA Becoming a CA(SA). https://www.saica.co.za/Training/BecomingaCA/tabid/157/language/en-ZA/Default.aspx

Steenkamp, L. P., R. S. Baard and B. L. Frick. 2009. "Factors influencing success in first-year accounting at a South African university: A comparison between lecturers' assumptions and students' perceptions". South African Journal of Accounting Research 23(1): 113-140.

University 1 (Uni 1). 2017. Admission requirements http://www.Unil.ac.za/prospective/undergraduate/ admissionrequirements/11644/admission_requirements_nsc.html

University 2 (Uni 2). 2017a. Guidelines for admission to Uni 2 for holders in 2017 of National Senior Certificate (NSC). https://www.uni2.ac.za/downloads/uni2.ac.za/apply/apps/undergrad/uctadmis guidelines_2017.pdf

University 2 (Uni 2). 2017b. Faculty of Commerce: Admission requirements, http://www.commerce. uni2.ac.za/Pages/Prospective-Students

University 3 (Uni 3). 2018. Faculty Programme. https://www.uni3.ac.za/docs/libraries provider44/faculty-programmes/economic-and-management-sciences.pdf?sfvrsn=56e0a421_2

University 4 (Uni 4). 2018. University Programme Information. http://www.Uni4.ac.za/en/yearbooks/ 2016/pdf/programme/07130042 
University 5 (Uni 5). 2018. Undergraduate admission requirements. http://www.uni5.com/assets/File/ Elektronic_book_Eng_print2.pdf

Uyar, A. and A. H. Güngörmüş. 2011. "Factors associated with student performance in financial Accounting courses". European Journal of Economics and Political Studies 4(2): 139-153.

Van Rensburg, P., G. Penn and M. Haiden. 1998. "A note on the effect of secondary school Accounting on university Accounting performance". South African Journal of Accounting Research 12(2): 93-99.

Van Wyk, E. 2011. "A note: The SAICA Part I Qualifying examinations: Factors that may influence candidates' success”. South African Journal of Accounting Research 25(1): 145-174.

Woollacott, L., D. Snell and S. Laher. 2013. Transitional distance: A new perspective of conceptualizing in the transition from secondary to tertiary education. Proceedings on the 2nd Biennial Conference of the South Africa Society for Engineering Education. 11-12 June, Cape Town.

Xiang, M. and R. Gruber. 2013. Student Performance in their first postsecondary Accounting course: Does high school Accounting matter? Advances in Accounting Education: Teaching and curriculum Innovations 13: 297-311. Boston Spa: Emerald. 